Paulo da Silva Quadros

Pesquisador do Núcleo de Educação

a Distância da Faculdade de Educação

da USP e do Centro de Cibernética

Pedagógica da ECA-USP.

\title{
CIBERESPAÇO \\ E VIOLÊNCIA SIMBÓLICA
}

Fortalecer os valores coletivos para uma vida cidadã é a fórmula segura para combater a banalização da vida e a violência no ciberespaço

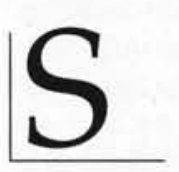

em dúvida, o século XX inovou surpreendentemente na questão da acessibilidade à informação. $\mathrm{O}$ acesso tem-se tornado o grande investimento dos mercados especializados em nichos tecnológicos. Assim, facilidade e rapidez a um volume vertiginoso de informações é a grande meta da sociedade dita globalizada, cujas palavras de ordem são competitividade e empregabilidade. Do toque do dial radiofônico, ao zap televisivo, e ao mouse informático, todos estes elementos prescrevem a busca ergonômica ideal para manuseio de informações midiáticas em doses combinatórias de acessibilidade.

No entanto, com tanto aparato tecnológico de acesso às informações, muito pouco a sociedade moderna tem feito para refletir, a priori, e até mesmo $a$ posteriori, sobre a qualidade dos produtos informacionais veiculados por todas as espécies de mídias existentes e, princi- palmente, aquelas que obedecem a um contato de caráter ao mesmo tempo público e domiciliar.

Pelo princípio do desvirtuamento do sentido de livre expressão da imprensa e da mídia em geral, constata-se uma banalização recorrente nos conteúdos programáticos dos meios de comunicação regularmente instituídos, de acentuada exacerbação no incentivo ao desrespeito à ética e à cidadania dos indivíduos. Não são raros os programas sensacionalistas na mídia televisiva que exploram a vida deteriorada dos excluídos, para infundir um senso falso de resgate de sua cidadania. Assim, familiares, vizinhos, marginais, deficientes, enfermos e personalidades são o constante alvo do expurgo e da catarse midiática. Por eles, chorase, lastima-se, sensibiliza-se e, ao mesmo tempo, reverencia-se, odeia-se, lincha-se, ora exaltando-se, ora apedrejando-se. Os sentimentos alteram-se, porque o julga- 
mento é um jogo de encenação bombástica e assim imprime-se vultosamente o desrespeito, para depois resgatá-lo homeopaticamente, se houver tempo suficiente no horário programado. Faz-se assim a exploração da condição humana com base na exclusão social, violando-se os princípios básicos de respeito aos direitos humanos, configurando a intolerância como um aspecto saboroso de realização e autoconhecimento da realidade social.

$\mathrm{O}$ que ocorre em relação ao ciberespaço é, conseqüentemente, a mimeses do bem sucedido em outras mídias: o ingrediente eficaz para a conquista de um grande público.

\section{Arrisca-se pouco, investe-se mais no sucesso fácil, no altamente lucrativo, renovável, superficial e sensasionalista.}

Nesse sentido, há uma troca de valores mercadológicos entre todas as mídias existentes. $\mathrm{O}$ ciberespaço acaba sendo o último e o mais livre dos espaços de experimentação do grotesco e do bizarro midiatizado, justamente pelo seu caráter desregulamentador.

O importante é a informação encontrar seu receptor em larga escala. Não há preocupação com a qualidade, pois o lucro fácil é inimigo da sofisticação. Educar, instruir, preparar não são metas, nem interesse desses veículos, voltados mais ao entretenimento de massa, adaptando interesses mercadológicos às necessidades das demandas carentes. O espaço da violência, por exemplo, preenche o vazio preconizado pela falta de alternativas para se vencer a barreira da dificuldade socioeconômica. Assim, vive-se intensamente o presente, pois o futuro é incógnito, não havendo sonhos, ideais e desejos a serem projetados como meta a longo prazo. Assume-se o presente como o tempo do máximo a se viver e, desta forma, a criança, o adolescente e mesmo o jovem ou adulto violentam-se ao destituírem-se da visão de um futuro proeminentemente feliz, acalentado, possivelmente, por grandes realizações.

\section{EXPLOSÃO DA VIOLÊNCIA SIMBÓLICA}

A violência é a grande preocupação de toda a comunidade mundial. No entanto, ainda se questiona de maneira insuficiente o culto hedonista à violência: prática idolatrada pelos filmes de ação com mortes banalizadas, pelos esportes radicais de violência física amplamente televisionados, pelas chamadas sensacionalistas da imprensa marrom, pelos jogos de guerra dos videogames e pela tribalização de costumes violentos - através da constituição das chamadas gangues de rua e de academias de artes marciais; além, é claro, dos grupos pró-nazistas, os quais encontram grande respaldo entre jovens desinformados, malformados, com baixa auto-estima, socioeconomicamente excluídos e espiritualmente flagelados.

A violência simbólica midiatizada expõe-se como foco de grande entretenimento domiciliar, quanto mais exacerbada $\mathrm{e}$ espetacularizada em sua encenação dramática e bizarra, conseqüentemente, maior é a gama de valorização que lhe é atribuída. Brinca-se de ser violento para atrair a atenção dos outros. Encena-se a violência com grau de sublimação e êxtase. 
Encara-se a violência como ato de orgulho visceral, autodefesa cívica, direito privado, ostentação e luxúria.

Nestes termos, a violência das ruas transfere-se para as telas, e a violência das telas, conseqüentemente encontra seu ponto escoador nas ruas e, a um toque, nas residências familiares.

Nesta explosão de violência midiatizada, as crianças são objetos e sujeitos de ações tenebrosas. Inúmeras são as histórias de meninos e meninas que matam acidentalmente colegas, parentes e irmãos. Sem consciência, agem apenas em função de um ato lúdico, fruto do imaginário infantil que procura representar aquilo que vê, ouve e sente, ainda no limite da realidade fantasiada, como se estivessem num parque de diversões onde as ações sucedem-se ludicamente, sem causa nem prejuízo. Como nos filmes e desenhos de TV, imagina-se um final feliz imemorável, sem se ter consciência da simbologia ritualística dos preceitos da realidade midiatizada.

No espaço cibernético, a violência simbólica amplia-se para níveis assustadores. Uma vez que não se pode controlar o conteúdo veiculado, as crianças que têm acesso facilitado a este meio, podem ser colocadas em contato com vários graus de perversidade humana: drogas por computador, manuais para construção de bombas, programas de computador para rastreamento de senhas e quebra de segurança de sistemas computacionais de grandes empresas, cibersexo - amostras de sexo bizarro, sexo violento, transexua- lismo, taras sexuais, sexo escatológico etc. Toda a perversidade sexual agora está ao alcance de alguém com um computador, placa de fax/modem, linha telefônica e acesso à Internet. Muitos desses serviços sexuais são pagos, mas oferecem sempre amostras grátis para os visitantes que desejam fazer um tour pelos sites pornôs. Além disso existem serviços gratuitos de propaganda dos diversos perfis de sites sexuais, o interessado só precisa, para acessá-los, dizer distantemente que é maior de dezoito anos, o que contudo não é atestado pelos provedores de serviços desta natureza, para os quais o que importa é a lucratividade, acima de qualquer propósito. Há também taxas baixas, para a obtenção de alguns serviços do estilo cyberporn, e qualquer um pode ter acesso a eles, desde que um cartão de crédito permita obter autorização do provedor do serviço.

Já é bastante comum ouvir-se falar dos casos de crianças e adolescentes que utilizam descontroladamente os serviços de disksexo, sem conhecimento dos pais. Já também não são mais novidade alguma os casos de crianças e adolescentes que empregam desautorizadamente os cartões de créditos dos pais para terem acesso a serviços cibermarginais, encontrando nestes um forte motivo lúdico de entretenimento com os colegas que também freqüentam o ciberespaço. Fazendo por fazer, trocam por correio eletrônico fotos e filmes pornôs, descobrem as senhas de acesso dos colegas e empregam seus endereços eletrônicos para execução de atividades clandestinas, quebram as senhas de sistemas de grandes empresas, modificam páginas de websites privados. 


\section{GERAÇÃO DIGITAL: PERIGOS}

Houve um tempo em que filhos aprendiam com pais, tios e avós. Agora, no tempo da tecnologia digital, as novas gerações de crianças é que ensinam os pais e adultos na tarefa de lidar apropriadamente com a tecnologia. A causa principal para que as crianças tenham, muitas vezes, mais êxito no uso de computadores do que os adultos reside no fato de elas utilizarem o equipamento sem tecnofobia, a partir do paradigma de tentativa-erro, da ludicidade no exercício de auto-aprendizagem, o que requer tempo e paciência e, ao mesmo tempo, destreza de assimilação conceitual. A criança pode ainda não ter o domínio da metalinguagem para abstrair os fenômenos de operacionalização como o adulto o faz, mas certamente tem a habilidade despreconceituosa para aprender fazendo, e aprender a apreender com o ato de fazer, construindo seu próprio conhecimento informático na forma do construtivismo contextualizado.

Pelo fato de a aprendizagem da informática obedecer a um caráter essencialmente lúdico, há indubitavelmente a necessidade de se operar com a construção de valores associados ao manuseio e acessibilidade à informação, os quais a informática e/ou a telemática geram assombrosamente. Alguns desses valores fundamentais seriam os conceitos que integram atitudes de ética e cidadania cibercidadania para o caso do ciberespaço. Inter-relacionado a isso está ainda a importância de se ter em mente a idéia de projetos individuais e coletivos bem articu- lados. A questão da síndrome informacional aliada à liberação dos instintos e das manifestações que o ciberespaço acolhe em seu ambiente, deve merecer maior interesse por parte dos educadores interessados em compreender o fenômeno do ciberfascínio que habita o consciente coletivo das crianças. A novidade na forma de cultura tecnológica do ciberespaço ou cibercultura atrai sobretudo as crianças, por significar um mundo admiravelmente novo para se comunicar e expressar livremente, sem limites ou punições. É, pois, no ciberespaço que as tribos de crianças e adolescentes, cada vez mais mundialmente iguais entre si, em função do contato midiatizado e globalizado de informações, travam seus encontros cibernéticos, liberando suas ações expressivas. A falta de maturação quanto à seleção de informação, contudo, provoca nas crianças e adolescentes um despreparo que se reflete conseqüentemente na vida real.

Muito uso de computador

e Internet pode potencializar anti-sociabilidade e insensibilidade para com o outro.

É nesse sentido que se fará necessária a função de um educador/comunicador educomunicador ${ }^{1}$, que atue como animador, questionador, mediador, engajador e contextualizador, capaz de desenvolver uma atividade de ensino-aprendizagem baseada na construção de redes de conhecimentos interdisciplinares e transdisciplinares com fontes multimidiáticas. 
O grande perigo para a geração digital, muito mais informada do que todas as gerações anteriores a ela, mas nem por isso bem-formada integralmente - pois apenas preparada segundo os preceitos fragmentários de conhecimento - é o de transformar-se em mero objeto ou instrumento para objetivos de consumo inconsciente ser objeto de sádicos, pervertidos, traficantes de drogas e profissionais do sexo perverso e da ciberpedofilia, que habitam vorazmente a Internet como lobos famintos atrás de cordeiros desgarrados.

\section{Não há fórmula mágica para combater a manipulação de crianças por parte desses profissionais contravencionais.}

Pode-se sim evidenciar a necessidade de se instituir na formação educacional das crianças, desde cedo, conceitos de valores individuais e coletivos firmemente enraizados e embasados a partir de uma matriz bem estruturada e construída através de alicerces de humanização. Deve-se ensinar o valor inestimável da informação quando produz conhecimento relevante para a vida cidadã ${ }^{2}$. O sentido de liberdade, auto-estima, respeito mútuo, sentido da tolerância entre indivíduos e responsabilidade social devem ser vistos como temas geradores de discussões enriquecedoras entre crianças, pais e educadores. Este deve ser o sentido de um escola inteligente em tempo de tecnologias inteligentes.

\section{SOCIEDADE EM REDE E IMAGINÁRIO INFANTIL}

Para entender a complexidade do ciberespaço e a cadeia de valores virtuais que o impregnam, é necessário, antes de mais nada, entender a dimensão humana e tecnológica do fato ciberespaço em si: o seu grau de organização social, a mimeses do real que opera no virtual, a cultura e a estética do ciberespaço. Enfim, conceitos fundamentais, tais como: cibercultura, ecologia cognitiva, redes de tecnociências e cultura de redes ${ }^{3}$.

Viver ativamente em uma sociedade de redes pressupõe apurar os graus de percepção de realidades concretas e abstratas, não num jogo entre concreto e abstrato, mas no entendimento da própria idéia de ambigüidade, complexidade e dialética entre concretização e abstração de conceitos.

A ecologia cognitiva, preconizada por Pierre Lévy, atesta a necessidade de uma metodologia que integre conceitos relativos a códigos, tecnologias e linguagens. Para o autor não haveria mais sentido em se ter uma visão estanque, especializada e estruturalista de conhecimentos disciplinares ${ }^{4}$. As redes

2. Ler entre outros MACHADO, Nílson. Ensaios transversais: cidadania e educação. São Paulo: Escrituras, 1997. (N. Ed.) 3. Ler sobre os conceitos LÉVY, Pierre, AUTHIER, Michel. As árvores do conhecimento. São Paulo: Editora Escuta, 1995. LÉVY, Pierre. As tecnologias da inteligência: o futuro do pensamento na era da informática. Rio de Janeiro: Editora $34,1993$. LÉVY, Pierre. O que é o virtual? São Paulo: Editora 34, 1996.

MARCONDES FILHO, Ciro. Pensar-Pulsar. Edições NTC, NTC, ECA/USP, 1997.

MARCONDES FILHO, Ciro. Redes comunicacionais. Atrator Estranho - revista do Grupo de Estudos "Nova Teoria da Comunicação". ECA/USP, Ano II, n. 6, maio de 1994 - Projeto Integrado com financiamento do CNPq. MARCONDES FILHO, Ciro. Super Ciber. A civilização místico-tecnológica do século 21. Sobrevivência e ações futuras. NTC, ECA/USP, Ática Shopping Cultural. Ciclo de Palestras de Eventos e Debates SUPERCIBER, junho de 1997. MORIN, Edgar. Para sair do século XX. Rio de Janeiro: Nova Fronteira, 1986.

4. LÉVY, Pierre. As tecnologias da inteligência... op. cit. 
de tecnociências, por sua vez, integram suporte tecnológico robusto para agregar grandes bases de conhecimentos científicos. A cibercultura, produto da estética do ciberespaço e, por conseqüência, do esteticismo de uma cultura híbrida, favorecida por jogos de metarmorfoses e antropofagias em tecnologias cibernéticas, é a manifestação da expressividade coletivizante nas redes telemáticas. Por último, a cultura de rede tenta ser uma abordagem conceitual que inter-relaciona redes humanas e tecnológicas, no sentido de aprender e apreender o meio rede, decifrar seus códigos de metalinguagens tecnológicas, interpretar as características cognitivas do ciberespaço e vislumbrar o ciberespaço como ponto de articulação e reflexão de toda a atividade socioeconômica, realizada no mundo real e desdobrada a partir da virtualização do mundo das relações humanas.

A dualidade entre objeto (real) e imagem (virtual) é a matriz geradora, no ciberespaço, de todo o imaginário humano. É neste novo espaço que se vislumbram as infinitas possibilidades de concretização de sonhos, ideais e projetos de um mundo mais justo e humanizado. O imaginário infantil reescreve o anseio de participação e interação com o mundo existencial, por parte das crianças. A superproteção à qual elas são submetidas, restringindo seus espaços de contato com a realidade social e, muitas vezes, periférica ao mundo que as circunda, leva estas crianças às distorções culturais no ciberespaço.
O mundo da superproteção, do culto da ostentação e do sim extremado potencializa intolerância com os menos favorecidos, tornando-os indesejados e inoportunos.

Nesse âmbito, a beleza muitas vezes torna-se apenas um pretexto de superficialidade estética, conforme os ensinamentos de valores desvirtuados do sentido de tolerância e humanização. Pouco se cultua na criança o senso apurado de beleza interior e de integridade moral. Supervaloriza-se o senso de aparência vital como requisito de sucesso e reconhecimento social, tornando-a presa fácil do culto à violência. $\mathrm{O}$ ambiente cibernético amplia as capacidades de violação de direitos, de prática de arbitrariedades, antieticidade, antimoralidade e atividades presumidamente egoístas.

No ciberespaço todas as mentiras tornam-se verdades e todas as verdades tornam-se mentiras à luz da vontade de seus artífices e freqüentadores. É assim que, por exemplo, contesta-se toda a história do holocausto, registrada a partir de documentos comprovadamente irrefutáveis. Diz-se que os documentos são provas forjadas pela grande mídia a partir de tecnologias de simulação altamente eficientes. $\mathrm{O}$ triunfo da vontade cibernética gera, inventa, mitifica, idolatra, idiotiza, transgride e desmoraliza habilmente através de simulacros do real. Como então, num ambiente de alta simulação 
tecnológica, é possível instituir regras de conduta ética e moral?

Propor soluções de formação educacional para a questão da banalização da vida e instituir grandes valores positivos como ética e cidadania, para todo o processo formativo do indivíduo, requerem interesses conjuntos para se apurar mais adequadamente o emprego educativo das novas tecnologias educacionais e dos meios de comunicação ${ }^{5}$. A criança, desde sua tenra idade, deve ser estimulada a cultivar em seu íntimo aspectos positivos de vitalidade, como o fascínio pela vida e o sentido de beleza pela arte, ciência, cultura e esporte. Os valores cidadãos ou

Resumo: O autor discute a banalização da violência e da vida nos conteúdos dos meios de comunicação, dando destaque especial aos conteúdos que circulam na Internet. Ele explica como a rede mundial de computadores, através do denominado ciberespaço, deixa ainda mais vulnerável a ataques de todos os tipos as crianças e os jovens que têm acesso livre ao mundo virtual, sem o adequado acompanhamento, na escola, do educomunicador e, na família, sem a formação sustentada em valores éticos e humanistas. Sua preocupação sustenta-se no fascínio que as novas tecnologias despertam sem a contrapartida valorização da convivência cidadã, ou seja, do respeito ao e reconhecimento do outro.

Palavras-chave: violência, Internet, ciberespaço, cidadania, valores éticos valores construtores de cidadania devem ser reavivados como forma de afirmação pela beleza da natureza humana e pelo sentido de civilidade/civilização.

O fascínio pela tecnologia por parte das crianças e adolescentes pode ser utilizado como um instrumental cativador e sedutor do espírito de construção da vida comprometida com valores sociais. Para isso, é vital definir e eleger estratégias de formação educacional adequadas, através das quais se desenvolva uma metodologia de ensino-aprendizagem apoiada numa pedagogia de projetos, estimulando a participação e colaboração ética entre alunos, professores e comunidade.

\section{(Cyberspace and symbolic violence)}

\begin{abstract}
The author discusses how violence and life itself have been made banal in the media's contents, giving special emphasis to content that is posted in the Internet. He explains how the World Wide Web, through the so-called cyberspace, makes children and young people who have free and unguided access to the virtual world even more vulnerable to all sorts of attacks. Such guidance is not found in the school, with the "educommunicator", nor in the family. There is no sustained upbringing in ethical and humanistic values. His concern is based on the fascination the new technologies cause, without a compensation of one living with other people as true citizens, in other words, mutual respect and acknowledging other people.
\end{abstract}

Key words: violence, Internet, cyberspace, citizenship, ethical values 